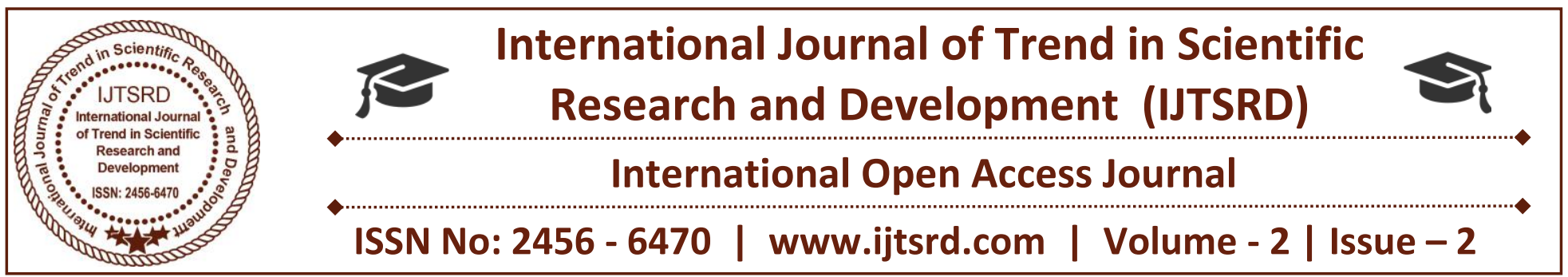

\title{
Reconstruction of European Geopolitics with a Special Reference to Mackinder's Heartland Theory
}

\author{
Anindita Mukherjee \\ Lecturer, Department of Geography, \\ Magrahat College, West Bengal
}

\author{
Mallicka Banerjee \\ Lecturer, Department of Geography, \\ Naba Barrackpur Prafulla Chandra \\ Mahavidyalaya, West Bengal
}

\section{ABSTRACT}

European geopolitics has been ever been a matter of discussion for the political geographers. The geostrategic theory of Halford Mackinder has helped in organising the thoughts in a proper way. Mackinder's theory was written under a tensed environment when European nations were preparing themselves for a great conflict either to safeguard their sovereignty or to glorify their nation. The theory was changed by the author several times as European politics never stood still since 1904. This paper tries to review the great events of European history that led to even greater political rearrangements. Renaissance was the first leap towards modern Europe followed by Industrial Revolution when European nations formed colonies in Asian and African countries with an economic motive. This eventually turned into a competition giving rise to dissatisfaction, aggression and discontent which ultimately led to World War I. Germany after the first war again arranged the arena for another war. The Second World War ended by inviting Cold War by dividing the world into two blocks; one around the Soviet Union and other one was United States. Gradually, Europe divided into two parts, Western Europe allied with the United States and Eastern Europe became the devotee of USSR. From that time, USA always tried to establish a policy which directly hamper the development of Russian territory specially reference to Germany. As a result, during 1945 Germany was divided into two parts namely Western and Eastern Germany. At 1990s, Germany was reunited with the crumple of communism and a modern geopolitics was started.
Germany was again the most powerful States under European Nation; consistently supports policies aimed at advancing EU-NATO cooperation. USA in 2004 tried to establish world hegemony by military intervention in Eastern Europe, USSR and Central Asia to weaken their unity which might be a threat to American supremacy. So, with the different interventions of event, a very clear notion has come that the geographical proximity of the Pivot area still exists.

Keywords: Geopolitics, Europe, USA, Cold War, Germany, Pivot

Political Geography establishes the relationship between the physical environments and the political condition and it change over time of different place on earth. In different natural condition different political essences are revealed by political geography. It is merely called a subdivision of geography but its subject matter is vast to be considered. From the day of very beginning of civilisation the journey of political geography has started. Its subject matter is not static. Every region of earth is different in various physical characteristics likewise every region has diverse political entity. Among all the regions of earth Europe has a diverse socio political history. No doubt its variety of physiography, climate, and vegetation has made it attractive for various races. To be precise Europe got united out of the need of withstanding the Asian invasions. 
Some major historical events of Europe like Renaissance, industrial revolution led to political changes of its countries. The history of Europe significantly starts with its first Revolution with the collapse of Carolingian empire in the tenth century (Moore, 1987). Early modern European history requires one to be familiar with the whole range of the basic themes, facts and developments of that region: the economic, and political crisis of Europe in the later Middle Ages to the first stirrings of the so-called Industrial Revolution; the Hundred Years War; the Great Schism and the conciliar movement; the Renaissance, humanism and the Reformation; the expansion of Europe into the so-called new world and its commerce with Asia; the so called Scientific Revolution; the wars with in France, Germany, and England and so on. (Fasolt, 2011).

The renaissance started in Italy in 1300 and spread to rest of the Europe around 1450. It marked the end of Christian-German civilisation and the beginning of modern European history and modern government as well. It was mention worthy that Renaissance was mostly affecting the lives of upper class while the peasantry or working class were far preoccupied by the matters of livelihood. There was competition among the city states of Italy aiming at their lack of unity. As the Spanish and French armies invaded Italy caused the downfall of city states (Merriman, 2004), whereas territorial unification took place in Britain, Spain etc.

Industrial revolution paved the way for modern politics to set in. The inevitable result of it was colonialism. Some European countries could manage to conquer economically most viable colonies while others became disappointed and angry by not getting benefitted. This discontent and economic disparity gave birth to an emotion of nationalism which later on proved to be a disease for the world which lead to wounds of first and second world war.

Modern Europe got framed after the incidence of industrial revolution of the nineteenth century. It was interesting to note the aftermath of industrial revolution throughout Europe. In eighteenth century it began in England. England was a resourceful country; soon development of heavy industry took place here. But at the same time many other European nations were still limited to agrarian economy. Two phases of development of industrial revolution could be identified one from 1760-1815 and secondly from
1815 onwards. Cotton was the first industry to be revolutionised (Hobson, 1902). In the later stages of industrial revolution use of petroleum could easily reduce the distance with far away continents. Thus the consequence of this revolution can be summarised as framing the cornerstone of capitalism. Industrial revolution resulted to excessive production and that too the need to find new markets for the goods, Europe was saturated already and the Europe headed to the East. Germany was an agrarian nation the revolution hit here late but she responded very fast to it transforming her to an industrial nation within a span of 30 years only. As an outcome of this revolution Europe took part in the game of Colonising countries of Asia Africa and America. It was interesting to note that not all the countries could have a good hand from this colonial race. The motive of colonisation was mainly economic. In this competition a few European countries could get most resourceful colonies but some countries could not gain that much economic benefit from this banter. This inequality enhanced the year old rivalries among European countries to many a times.

However economy not only led to colonialism, like other living being a nation also needed to grow with time, she also needed food and nourishment that could be achieved by amalgamation of adjacent weaker lands (Dikshit, 1999). Some writers readily welcomed imperial expansion. Now a very important theory of Geopolitik by Ratzel came in this perspective with an idea of unstatic border of nations. Geopolitics may be confined between two or more neighbouring countries but scientific advancement made the faraway lands accessible and result was friction and even wars between countries even far away from each other, this is reflected in the theories of geostrategy trying to meet a balance of power of the countries. In Europe most of the countries had a history of old conflicts but economic conflict made it naked. Great politicians felt expansion can only bring internal stability to a nation, a big a powerful nation can only gain respect out of fear from the world. Nations started to strengthen their armies rather they got engaged in a competition of army. All European nations were viewing the same dream of conquering the whole world. Britain, France, Germany, Portugal and Russia were forerunners of the race of colonialism. The patronage of royal families of various nation conducted voyages to farfetched lands of America, Asia and Africa. The foremost objective was to increase trade but the immense 
treasure of those newly discovered nations led to establishment of colonial empires (Thompson, 1957). French colonial Empire was in nations of North America, Caribbean Islands and India. British colonial empire consisted of nations of North America, Africa and Asia. German colonial empire was established in East Africa, Mamoa islands, New Guinea and Cameroon. Russian colonial empire comprises nations from Black Sea to Pacific coast and in parts of America. In several regions of North and South America Spanish colonial empire was based on (Pounds, 1963).

In The Mean Time in Europe situation heated up as to fulfil political motives the nations who once met in the battlefields or were old rivals had to form groups, this caused political unrest and the seed of First World War was put in ground. A series of small but significant wars led to the big event. In 1875 war officially commenced between Germany and France. Germany made allies with Austria and Italy forming 'League of Three Nations' while England took the side of France later on joined by Russia. While these nations were engaged in direct conflict the media and scholars of concerned nations continuously ignited the fire of nationalism from within. It was interesting to note that the present allies Britain, France and Russia considered themselves enemy of each other in past but the rise of Germany with a grand navy necessitated the unity of the above mentioned nations.

The first chancellor Bismark who engineered a series of wars that unified the German states into a powerful German Empire under Prussian leadership, according to him Germany was a satiated country and had no intention to make any further expansion of her territories. He tried to maintain a balance between the contending European powers. After the Berlin Congress Russian wrath was against Germany, hence he felt the need off making alliance with Austria. Later Russia approached with a suggestion of reviving the old Three Emperors League of Russia, Germany and Austria-Hungary (Guha Roy, 2010). Many political ups and downs governed the European politics in the coming years. But the following most important event to take place was First World War, though it started in Europe but it certainly had a global effect as the colonies became part of the war indirectly. The war was actually the end product of a long sequence of events which began in 1871 but it officially started in 1914. As history reveals no European country wanted this war but it was an outcome of long nurtured hatred and untamed nationalist feeling. Many historians opine this war was merely fought to save one's own territory to secure country's pride and sovereignty. The annexation of Alsace-Lorraine gave new fuel to French nationalism and promoted Germanophobia in France. Germany and England always had an intention of forming a great empire on the other hand France, Italy and Serbia had lost their lands so it was their nationalist feeling that led them to the war. Even situation of smaller Balkan states grew worse when peace treaties were dishonoured and their existence crisis became threatened (Thompson, 1957).

The war officially commenced between Serbia and Austria. When whole Europe was engaged in war a vital question came to the minds of great thinkers and scholars that who will become the ruler of the world?? (Mackinder, 1904). Many tried to solve the riddle by forming theories but which advancement of world politics the theories also changed.

In this context the theory of Halford Mackinder had tried to foretell about the leader of the world politics. Halford Mackinder was a social determinist. He always tended to superimpose the effect of physical environment on its political condition. It was rightfully an attempt to correlate between the larger geographical and the larger historical generalizations. Countries of Europe were involved in friction from the very beginning of history; this was the underlying fact of Mackinder's theory. He made several changes to the theory so a reflection of the changing politicogeographical scenario was very vividly postulated. In 1904 at Royal Geographical Society Mackinder published a writing named "The Geographical Pivot of History". As a Member of Parliament it was rather a warning for the British to strengthen their armies for the advancing German troops.

Mackinder pointed to the pivotal nature of the vast Eurasian region, inaccessible to sea-going vessels, but an easy target for the nomads in antiquity. Mackinder was convinced that Eurasia possessed sustainable conditions for the development of military and industrial powers. He considered Eurasia as World Island. The geographical pivot according to him was the centre of political power the European nations will fight for was later named heartland in 1919. Lands of Russia, China, Mongolia, Baluchistan and Iraq cover the heartland. Geographically the area was unique with Arctic sea in north Himalaya in south, Siberia in 


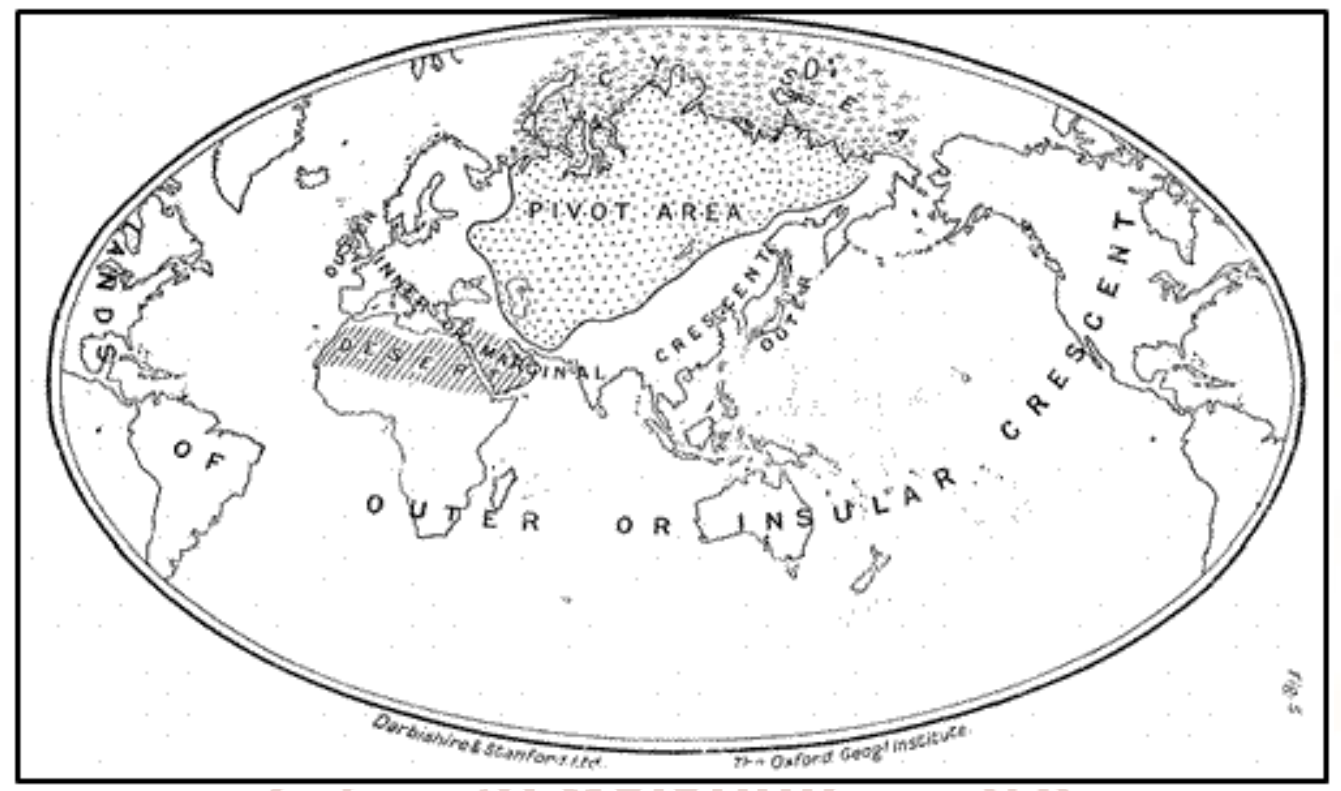

Figure 1: Mackinder's 'pivot area', the 'inner' and 'outer crescents': Source: H.J. Mackinder, 'The Geographical Pivot of History', The Geographical Journal, vol. 24, no. 4, 1904, p. 435.

east and Volga River in west. This is an area of inland drainage which is merely impregnable expecting a narrow corridor through Caspian Sea. This region is also full of natural resources like fertile agricultural land for development of agriculture and plain land to set up transportation routes and industries. From past the great leaders wanted to keep a control of this land. As per Mackinder after the world war one who will capture the heartland will be ruler of the earth. Mackinder was anxious about the rise of pivot area and wanted his country to check by maintaining the marginal areas. He feared that Germany may one day capture the heartland then the coastal crescent will be exposed and easily conquerable endangering the sovereignty of England. On the other had there was a fear of the dominance of China over Russia then China and Japan may form a yellow peril. In 1919 with the end of the world war Mackinder again made changes to his theory as Germany made an attack to Russia through steppe corridor so he thought the countries between Germany and the heartland should make a buffer for the protection of heartland. (Ochssée, 2007)

The First World War ended with Treaty of Versailles where Germany was accused for the war and had a burden of great compensation to pay. All these were to destroy the backbone of the nation. The war had various consequences in politico geographical point of view but the remarkable ones were monarchian crisis as the four great empires of Hungary-Austria, Turkey,
Russia and Germany fell. The big power of east Europe was disintegrated into small independent nations of Czechoslovakia, Poland, and Yugoslavia etc.

After this devastating war peace was the call of the time. Thus League of Nations was established but it failed to restore peace and the abnormal nationalist feeling led to another world war. World War II is considered to be the continuation the previous world war. It was basically to take revenge of the previous war. In Germany economy collapsed, people were starving and in the midst of all these there was not any air for the democracy to live. The power went into the hands of Hilter and his Nazi party with his plan in mind to form a 'Great German Nation' by unifying all Germans throughout the Europe followed by a cleanup of 'non German' Jews from the country. The rise of fascism by Mussolini and military expansion of Japan formed the platform for the war. Germany was supported by Italy and Japan. Although the war weary British and French followed the policy of appeasement to Hilter but he deliberately opposed the treaty of Versailles by military expansion and Britain finally marched against Germany officially breaking out the world war. The geographical territory of the second war was even wider, Asian countries were now directly involved in the war.

The various images of politics of that time and its change were portrayed by Mackinder in his book of 
'The Round World and Winning of Peace'. After The Defeat of Germany in World War II Mackinder no more considered it compatible to capture heartland rather he saw a possibility of a nation within heartland to rule it as the war marked the rise of two superpowers- Russia and America. The Eastern Europe eventually went into the hands of Russia while the west was reorganised by America (Foster, 1974). The end of the Second World War did not provide any platform which brings the global powers to a peaceful space. On the converse, it resulted in a new invisible conflict. Gradually the whole world divided into two power blocks; one around the Soviet Union and other one was United States. Simultaneously, other countries were being forced to choose any one power blocks. The United States was the immense defeater of World War as it's looses less human and material during the war and it became world's leading military power. It was the only country with the capacity to produce nuclear weapons (In 1945, USA dropped the atomic bomb namely Little Boy in Japan). It also confirmed its status as the world's leading economic power, in terms of the production of Industrial and Agricultural products. (Roberts, 2005)

The Cold War was a prolonged struggle between the United States and the Soviet Union that began with the surrender of Hitler's Germany. The Cold War was not completely about the struggle between the US and the USSR but it affected much too the European continent. As a result, whole Europe divided into two parts, Western Europe allied with the United States and Eastern Europe became the devotee of USSR. The policy taken by United States was very hostile against the development of Russian territory which directly put its impact on Germany. During 1945, western allies gradually occupying the different parts of Germany; USA occupied the Southern part, British occupied the West and North portion, France the South-West, and the Soviet controlled the Central Germany. The Eastern part was administered by Poland, except the town of Kaliningrad, which were annexed by the USSR. As a result, whole Germany divided into two parts Eastern and Western on the basis of dominated power. (History, 1991)

As per the heartland theory it met apprehension as well as criticism with the US-USSR rivalry claiming to be 'the pivot of Asia on one side and on the other side as application of Mackinder's idea to contemporary Asia will be misplaced.
During 1947-48, Western allied became more threatful towards the technological development of Eastern Europe around Germany. Therefore, United States demanded for a more powerful support from France and UK. From 1949, Western Europe felt the economic fall and sought for help from US alliance. In the mean time, US also joined with the NATO to secure the ocean from territorial out fall. The North Atlantic Treaty Organization thus devoted to United States military support for collective security in Europe. It permanently linked the United States and Europe on behalf of internal security. Here again the European continent played a very crucial role in determining the world power politics.

Nevertheless the two Great Powers never came directly in the battle ground; they pressed the world on behalf of economic and geo-political power on several events. In, 1961 the formation of Berlin Wall was the major event which showed how the people of Germany is divided on the ideology based economic structure. Political expert Raymond Aron, faultlessly defined the Cold War as, it hits the nail on the Head: 'Impossible peace, improbable war'. By the end of 1989 to 1990, Cold War was announced to its end with the fall of the Berlin Wall and the crumple of the Communist regimes in Eastern Europe.(CVCE, 2016) The significance of Germany although it's crushing defeat in the World War II was never less. By the end of the Cold War, German unification showed a monumental shift in the geopolitical realities that had defined foreign policy of Germany. Germany was become the largest country of Europe once again, and the Soviet threat, which had served to unite West Germany with its pro western neighbours. Until 1994, Germany was constitutionally barred from deploying its armed forces abroad. Till 2008, approximately 7,400 German troops are deployed in peacekeeping, stabilization and restoration missions worldwide. However, the foreign policy of Germany was continuous to evolve. Since the end of the Cold War, the relationship of Germany with the United States have been shaped by various factors; which includes Germany's growing support for a stronger European Union, and its continued allegiance to NATO as the primary guarantor of European security.

Since unification, Germany has played a potential role behind the EU's enlargement eastward, integration of European countries, European foreign policy coordination, and the development of a European Security and Defense Policy (ESDP). Former 
European Chancellor Merkel argues that a more consistent European foreign, security, and defence policy device will in fact enable Europe to be more effective transatlantic partners to the United States. Germany consistently supports policies aimed at advancing EU-NATO cooperation. Berlin's dual commitment to the EU and NATO suggests that to find a middle path of cooperation between the two institutions. (Belkin, 2009)

After the seven decades of World War II, present geopolitical relations are not as profound as the world imagine. A majority of Germans believe it is more important for Germany to have strong ties with the United States than with Russia. For the Americans, most important event in U.S.-German relations over the past 75 years remains World War II and the Holocaust, to the extent of one event that is the 1989 fall of the Berlin Wall. In the eyes of most Americans, the "special relationship" with Britain is still stronger than that with Germany. Americans want Germany to play a more active military role in the world, but Germans insistently disagree. Economically and geopolitically, the U.S.-German alliance has become the key player of the trans-Atlantic relationship in the $21^{\text {st }}$ century. Despite their disagreements at the time over the Iraq War and U.S. National Security Agency spying, Americans and Germans view each other as reliable allies. (Germany and the United States: Reliable Allies, 2015).

On the ground of present geopolitical circumstances, Germany is one of the United States' contiguous allies in Europe. From the political point of view, Germany stands at the center of European associations and plays a key role as a member of the G-7, G-20, North Atlantic Treaty Organization (NATO) and the Organization on Security and Cooperation in Europe (OSCE). Most recently, the United States and Germany have been working closely together to counter Russian aggression in Ukraine, confer a political solution to the crisis in Syria, and to curtail the Iranian nuclear program.

In 2016, Germany hold the Chairmanship of the OSCE where they helped continue the OSCE's important work preventing conflict, promoting democracy, human rights and the rule of law, and encouraging open and transparent economies. The United States recognizes that the security and prosperity of the United States and Germany significantly depend on each other. (U.S. Relations With Germany, 2016)

The formation of Economic Union was very significant in uniting Europe and ending year long hostility through trade. Opening of domestic market and agreements on free trade gave a common mean for economic benefit for various nations. The Euro currency was an extraordinary step in making trade easier and represents a symbol of the close ties between the nations. (Bradley, 2012)

The debate grew afterwards whether or not the heartland theory is applicable to the modern circumstances. It was to be admitted that the geostrategic position of countries of heartland always tempted other countries to explore them. End of the Cold War didn't bring lasting peace as nations were still in competition which reprises many ideas of Mackinder. According to Dhaka, the antipodal arrangement of continents and oceans suggest a tetrahedral shape and the heartland buy virtue of its place in the tetrahedron is in the crucial position. US aimed at checking the influence of Russia in the pivot region using EU and NATO. With U.S war against Iraq in 2013 broke down the alliance of Britain and Germany. Britain belonged to the Outer Crescent and Germany was positioned at the intersection of Midland ocean world and Heartland. During cold war its former location proved to be better but after the fall of USSR its heartland location was reasserted as a decisive factor in policy making. After Cold War Britain was struck to its US alliance but Germany weakened it and re-invigorated EU. As UK tried to do in 1904, USA in 2004 tried to establish world hegemony by military intervention in Eastern Europe, USSR and Central Asia to weaken their unity which might be a threat to American supremacy. So it will not be totally wrong to consider the Heartland as power pivot in recent times also (Megoran, 2005).

One of the key problems of modern European Union is the 'interventionists' like the French and 'freetraders'- Germany. France wants to give safeguard to their national industries and ensure their safe economic future. This kind of protectionism is the most distinct anti-European strategy. On the other hand, the free traders, like Germany, want to impose less regulation to make European trade as a whole cheaper and more competent. However, unlike the Cold War these nations have many more areas of solidarity which remove the possibility of these small conflicts. (Bradley, 2012) 
This paper concludes that, till now Central Asia is playing a pivotal role in determining the world power politics. From the $2^{\text {nd }}$ world war, each power strives to control to the region's resources. For the European Union, the main goal is to achieve economic access while concurrently promoting the democratization of those countries that are politically unstable. Central Asia is considered as very influential to each power. However, in the light of Mackinder's notion of "the actual balance at any given time" shows the geographical proximity of the Pivot area. On the other hand, USA and EU are building up alliances with regional countries in order to maximize their economic and political influence (Scott \& Alcenat, 2008). Mackinder's theory also made has influenced Western powers' strategic thinking during the Cold War between the Soviet Union and the United States.

\section{REFERENCES:}

1. Adhikary, S. (1997). Political Geography. Delhi: Rawat Publication.

2. Belkin, P. (2009). German Foreign and Security Policy: Trends and Transatlantic Implications . Congressional Research Service.

3. Chowdhury, S., \& Kafi, A. (2015). The Heartland Theory of Sir Halford John Mackinder: Justification of Foreign Policy of United Stated and Russia in Central Asia. Journal of Liberty and International Affairs, 1-13.

4. Dahlman, C., \& Gallaher, C. (2009). Key Concepts in Political Geography. Delhi: Sage Publications India Ltd.

5. David, T. (1957). Europe Since Nepoleon. Penguin Books.

6. Dikshit, R. (1999). Political Geography, The Spatiality of Politics. Tata Mc Grow Hill Publication.

7. Dodds, K. (2005). Geopolitics : A Very Short Introduction. UK: Oxford University Press.

8. Dwivedi, R. (2007). Political Geography, The Spatiality of Politics. Allahabad: Chaitanya Publishing Home.

9. Esmailov, E., \& Papaya, V. (2010). Rethinking Central Eurasia, Central Asia Caucasus. Institute Silk Road Studies Programme.

10. Foster, M. (1974). The Wrld at War. London: BCA.
11. Friedrich, S. E. (2013). Germany and Russia in 2030. Berlin: German Federal Foreign Office.

12. Germany and the United States: Reliable Allies. (2015, May 7). Retrieved October 17, 2017, from Pew Research Center: http://www.pewglobal.org

13. Guha Roy, S. (2010). Europe 1789-1945. Pragatishil Proshak.

14. Hara, O., Heffernan, M., \& Endfield, G. (2005). Halford Mackinder, The Geographical Pivot, and British Perception of Central Asia. In B. Blouet, Global Strategy: Mackinder and the Defence of the West. London: Frank Class.

15. Hobson, J. (1902). Imperialism: A Study . U.K: Cosimo Classics.

16. Mackinder, H. (1919). Democratic Ideals and Reality: A Study in the Politics of Reconstruction. London: Constable and Company.

17. Mackinder, H. (1904). The Geographical Pivot of History. The Geographical Journal .

18. Mackinder, H. (1943). The Round World and the Winning of the Peace. Foreign Affairs .

19. Marriman, J. (2004). A History of Modern Europe: From the Renaissance to the Present. New York: W.W Norton.

20. Megoran, N., \& Sarapova, S. (2005). Mackinder's Heartland a Help or Hindrance in Understanding Central Asia's International Relations. Central Asia and the Caucasus.

21. Megoran, N., Sarapova, S., \& Faizullaev, A. (2005). Halford Mackinder's 'Heartland' - a Helpor Hindrance? The Geographical Journal .

22. Merriman, J. (2004). A History of Modern Europe: From the Renaissance to the Present. New York: W.W. Norton.

23. Moore, R. I. (2000). The First European Revolution, c. 970-1215. U.K: Oxford: Blackwell Publishers.

24. Morgan, S. (2005). Mackinder's "Heartland": A Help or Hinderance in understanding Central Asia's International Relations. Central Asia and Caucasus( Special Issue).

25. Ochssaa, B. T. (2007, July). Exploring Geopolitics. Retrieved November 2, 2017, from Exploring: http://www.exploringgeopolitics.org 
26. Palmer, R., Kolton, J., \& Kramer, L. (2013). A History of Europe of the Modern World. New York: Mc Grow Hill Publication.

27. Pounds, N. (1990). An Historical Geography of Europe. New York: Cambridge University Press.

28. Pounds, N. (1963). Political Geography. Delhi: Tata Mc Grow Hill Publishing House.

29. Scott, M., \& Alcenat, W. (2008). Revisiting the Pivot: The Influence of Heartland Theory in Great Power Politics. Macalester: Macalester College.

30. Siddhartha, K. (2000). Nation State , Territory and Geopolitics. Kishalaya.

31. Sloan, J. (1999). Sir Halford J. Mackinder: The Heartland Theory Then and Now. Journal of Strategic Studies .

32. Suri, J. (n.d.). Conflict and Co-operation in the Cold War: New Directions in Contemporary Historical Research. Journal of Contemporary History, 5-9.

33. U.S. Relations With Germany. (2016, December 21). Retrieved October 16, 2017, from U.S Department of State: https://www.state.gov

34. Ugarriza, J. (2009). Ideologies and conflict in the post-Cold War. International Journal of Conflict Management, 82-104. 